\title{
Genotypic variation in morphology and freezing resistance of Eucalyptus globulus seedlings subjected to drought hardening in nursery
}

\author{
Rafael E. Coopman* \\ Instituto de Silvicultura \\ Facultad de Ciencias Forestales y Recursos Naturales \\ Universidad Austral de Chile \\ Valdivia, Chile \\ E-mail: rafael.coopman@docentes.uach.cl
}

Jorge C. Jara

Departamento de Recursos Hídricos

Facultad de Ingeniería Civil Agrícola

Universidad de Concepción

Concepción, Chile

\section{Rene Escobar}

Departamento de Silvicultura

Facultad de Ciencias Forestales y Recursos Naturales

Universidad de Concepción

Concepción, Chile

\author{
Luis J. Corcuera \\ Departamento de Botánica \\ Facultad de Ciencias Naturales y Oceanográficas \\ Universidad de Concepción \\ Concepción, Chile
}

Leon A. Bravo

Departamento de Botánica

Facultad de Ciencias Naturales y Oceanográficas

Universidad de Concepción

Concepción, Chile

Keywords: biomass allocation, cross hardening, genotypic selection, planting stock quality, water stress.

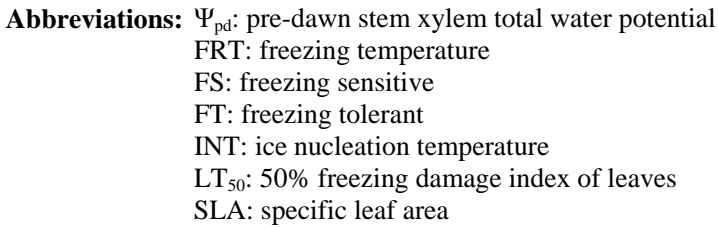

Abbreviations: $\Psi_{\mathrm{pd}}$ : pre-dawn stem xylem total water potential

FRT: freezing temperature

FS: freezing sensitive

FT: freezing tolerant

INT: ice nucleation temperature

$\mathrm{LT}_{50}: 50 \%$ freezing damage index of leaves

SLA: specific leaf area

Eucalyptus globulus Labill is one of the most planted species in Chile, because of its fast growth and superior pulp qualities. Nevertheless, the incidence of drought and frost damage immediately after planting is frequent. The purpose of this work was to study the effect of drought hardening on frost resistance and on variations in morphological traits that may increase drought resistance at nursery phase in four genotypes of E. globulus Labill. Drought hardening treatments consisted in induced water stress by watering restriction, until pre-dawn stem xylem water potentials $\left(\Psi_{\text {pd }}\right)$ reached -0.2, -1.8 and -2.6 MPa. Two water stressrewatering cycles were applied during 54 days of hardening. Plant and root biomasses were affected by the interaction of drought hardening and genotypes. The rest of morphological and alometrical traits were affected independently by drought or genotype. Plant height, leaf area, specific leaf area (SLA), stem, and leaf biomasses decreased with drought hardening, while collar diameter was not affected. Genotypes responded differentially to drought hardening in plant height, leaf area, SLA, and stem, and leaf biomasses. Ice nucleation temperature (INT), and freezing temperatures (FRT), and $50 \%$ freezing damage index of leaves $\left(\mathrm{LT}_{50}\right)$ were affected by the interaction between drought hardening and genotypes. EG-13, EG-23 and EG-22 genotypes became freezing tolerant with drought hardening (-2.6 MPa). Additionally, EG-14 genotype increased its

*Corresponding author 
freezing resistance at $-1.8 \mathrm{MPa}$. Therefore, freezing resistance levels and mechanism depend on genotype and drought hardening treatment. The success in tree breeding by genetic selection should be facilitated by improved understanding of the physiology of stress resistance development and survival during water supply limitations. The knowledge of morphological and freezing resistance dependency on the interaction between genotype and drought hardening may be useful nursery management information to improve plantation success.

Eucalyptus globulus Labill is one of the most planted species in Chile, because of its fast growth and superior pulp qualities. However, seedlings are inherently susceptible to drought, low temperature, and frost. These factors largely contribute to seedling mortality soon after planting (Close et al. 2004). The challenges to improve $E$. globulus capacity to withstand drought and freezing temperatures by resistant genotypes selection have received major attention (Pita and Pardos, 2001; Costa e Silva et al. 2007; Wikberg and Ögren, 2007).

Chilean forest companies have expanded and developed intensively in the last two decades. This has led to tree forest nurseries to incorporate the most modern container nurseries and vegetative plant propagation procedures. Plants develop succulent stem and leaves and high shoot:root ratios in response to the high nitrogen fertilization rates used during the full growth phase in nursery. These features make seedlings highly susceptible to drought and frost damage (Thomas and Ahlers, 1999;
Sundheim Fløistad and Kohmann, 2004; Villar-Salvador et al. 2004b). The final drought hardening phase under nursery conditions induces leaf morphological and seedling biomass allocation modifications which are closely linked with the survival of plants in unfavourable sites with seasonal drought (Royo et al. 2001; South et al. 2001; Coopman et al. 2008). Seedlings exposed to sub-lethal water stress cycles in nurseries exhibit less drought injury in field than non stressed plants (van den Driessche, 1992; Villar-Salvador et al. 2004a). Changes in drought tolerance depend on the degree of water stress, the length of the hardening period, and the species (Royo et al. 2001; Wikberg and Ögren, 2007). There is limited information about morpho-physiological variations induced by a drought hardening phase under nursery conditions of $E$. globulus genotypes adapted to ambient conditions in Chile (Coopman et al. 2008). Plants respond to water deficit by reducing growth rates and water loss. During acclimation to water stress, adjustments in architecture and intrinsic physiology can occur (Ewers et al. 2000). Leaf shedding and root growth triggered by water stress (Linder et al. 1987) result in decreased shoot:root ratio, which favours a high water balance during drought (Ewers et al. 2000; Hsiao and $\mathrm{Xu}, 2000$ ). Plant morphological attributes such as collar diameter and plant height have been consistently reported as good indicators for survival and growth potential after planting (Mason, 2001; Haase et al. 2006). Finally, there is evidence that cold acclimation and water stress induce cell dehydration. This water loss triggers a series of common physiological responses, such as accumulation of solutes (Beck et al. 2004). These solutes decrease protoplast osmotic potential and may cryoprotect

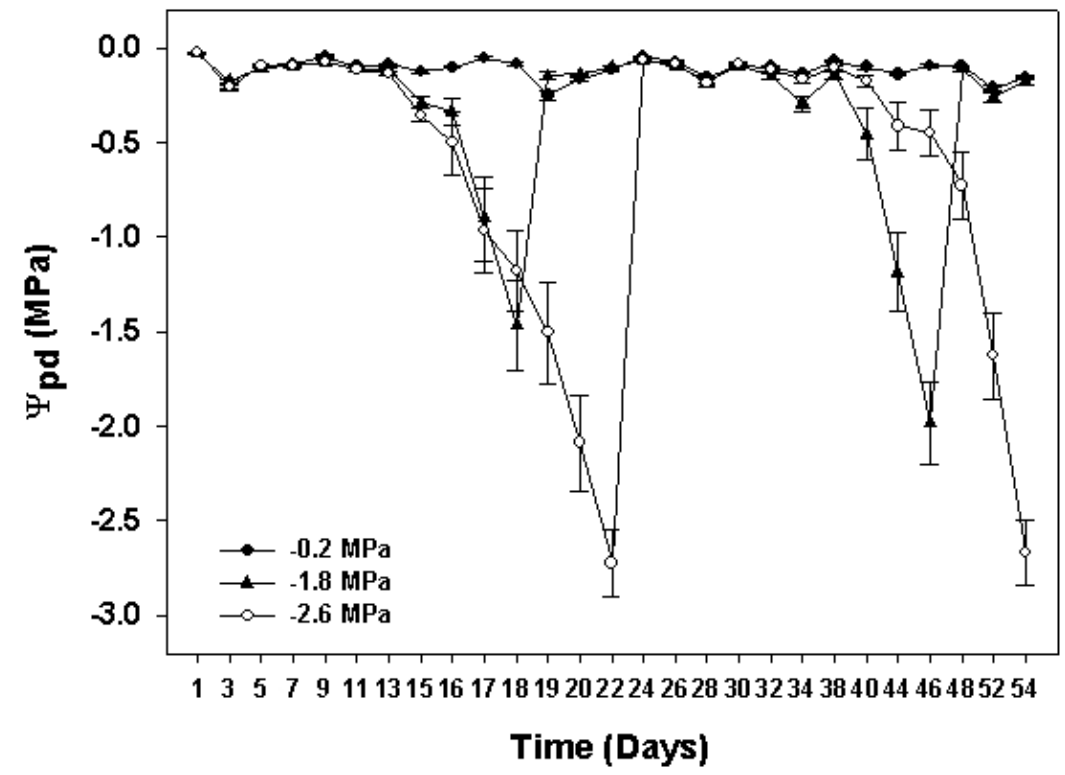

Figure 1. Variation of pre-dawn stem xylem water potential $\left(\Psi_{\mathrm{pd}}\right)$ of the average of four Eucalyptus globulus genotypes during drought hardening time course. Three drought hardening treatments were applied during 54 days (May-June 2004), consisting of two cycles of watering restriction until certain stem water potential were reached $(-0.2,-1.8$ and $-2.6 \mathrm{MPa})$. After the target water potential was reached, plants were thoroughly watered until substrate saturation. Error bars represent $\pm 1 \mathrm{SE}, \mathrm{n}=80$. 
freezing labile cell structures. Furthermore, products of drought induced genes may also be involved in freezing resistance (Pearce, 2001; Beck et al. 2007). Development of cold hardiness is initially related to a reduction in water content and then to changes in the physical state of water (Shvaleva et al. 2008). Solutes that accumulate during water stress may bind to water, affecting even more the physical properties of water. It has been proposed that drought resistant genotypes of Eucalyptus globulus have a greater cold tolerance than drought susceptible ones (Costa e Silva et al. 2009). Moreover, physiological and morphological changes are differentially induced in different genotypes (Pita and Pardos, 2001). Differences in leaf anatomy influenced the formation of ice and the pattern of frost injury in three evergreen tree species from New Zealand (Neuner and Banister, 1995). Also, genetic variation in frost resistance of Eucalyptus globulus have been reported (Tibbits et al. 2006). The purpose of this work was to study the effect of drought hardening on frost resistance and on variations in morphological traits that may increase drought resistance at nursery phase in four genotypes of E. globulus Labill.

\section{MATERIALS AND METHODS}

\section{Plant material and treatments}

A total of 11,200 eight month old rooted cuttings of Eucalyptus globulus Labill, divided in 4 sets of 2,800 plants of each genotype evaluated (EG-13, EG-23, EG-14 and EG-22), were obtained from the Forestry Company Bosques Arauco S.A. Chile. Cuttings were rooted in trays of 88 containers of approximately $130 \mathrm{ml}$ each, using a mixture of turf:perlite $1: 1(\mathrm{v} / \mathrm{v})$ with a total porosity, aeration and water retention of $75 \%, 32 \%$, and $42 \%$ respectively. The growth density was 393 plants $\mathrm{m}^{-2}$, in a greenhouse with mist irrigation. After rooting, plants were grown outdoors for 5 months. For drought hardening, these plants were kept under a transparent roof in order to avoid water from rainfall. Daily maximum and minimum air temperatures and relative humidity, wind speed, and maximum PPFD were determined at foliage level with a weather station (Datalogger $21 \mathrm{X}$, Campbell Scientific Inc., Logan, Utah) with temperature and relative humidity sensor (CS500-L, Campbell Scientific Inc., Logan, Utah), and an anemometer (Vector Instruments Type A 100 L2, N. Wales, United Kingdom) and piranometer (LI-COR LY200 Biosciences, Lincoln, NE USA).

\section{Drought hardening}

Three different treatments were applied and consisted in watering restriction until plants reached a pre-dawn stem xylem water potential of ( $\Psi_{\mathrm{pd}}:-0.2,-1.8$ and $\left.-2.6 \mathrm{MPa}\right)$. Plants were then watered to reach substrate saturation and a second cycle of drought started. The treatment with $\Psi_{\mathrm{pd}}=$ $0.2 \mathrm{MPa}$ was considered as a non-stressed control; the -1.3 MPa (moderate stress) value is in the center of the target range (-1.0 to $-1.5 \mathrm{MPa})$ for drought hardening processes that has been commonly used in most USA forest nurseries (Landis, 1989). It is just below to the wilting point of the experiment's seedlings. Finally, -2.6 MPa (severe stress) corresponds to a permanent wilting point of experiment's seedlings. The hardening phase lasted 54 days (May-June 2004) and included two cycles of low water potential (Figure 1). $\Psi_{\mathrm{pd}}$ was measured in plants of each genotype and treatment $(\mathrm{n}=20)$ with the Scholander pressure chamber (Soilmoisture Equipment Corp, Santa Barbara, CA, USA), approximately every two days. The treatment with $\Psi_{\mathrm{pd}}=-0.2 \mathrm{MPa}$ was watered with a frequency of about 7 days. $\Psi_{\text {pd }}$ did not change until day 13 and then decreased at a rate of $-0.27 \mathrm{MPa}$ day $^{-1}$ (Figure 1). The desired water potentials were reached at 18 and 22 days in the first cycle, respectively. After rewatering, the plants reached again the desired water potentials after 46 and 54 days, respectively (Figure 1). In order to uniform the humidity content of the substrate, before the beginning of the assay and immediately after the hardening treatment, plants were all watered as treatment $-0.2 \mathrm{MPa}$. Non significant differences in the $\Psi_{\mathrm{pd}}$ behaviour between genotypes were found during hardening $(\mathrm{P} \leq 0.05)$.

\section{Growth}

Forty plants from each treatment and genotype were collected at the end of the assay to determine plant height, stem diameter, and root, stem, leaf, and plant dry biomasses. Additionally, leaf area and specific leaf area were determined using a leaf area meter Li-3100 (Li-Cor Inc., Lincon, Ne USA).

\section{Freezing resistance}

Three weeks after the end of the hardening phase, 12 plants from each hardening treatment and clone were collected. Two leaf disks (8 $\mathrm{mm}$ diameter) were obtained from each third pair of leaves, which were the first totally expanded leaves. The leaf disks were placed into polycarbonate test tubes and exposed to freezing temperatures $\left(-3.0^{\circ},-4.5^{\circ}\right.$, $6.0^{\circ},-7.5^{\circ}$, and $-9.0^{\circ} \mathrm{C}$ ), without ice nucleating agents in a chamber cooled by forced air. The above zero cooling rate was $30^{\circ} \mathrm{C} \mathrm{h}^{-1}$ and below cero $2.1^{\circ} \mathrm{C} \mathrm{h}^{-1}$. The time of exposure to each target freezing temperature was 1.5 hrs. Then, leaf disks were left to thaw at $4^{\circ} \mathrm{C}$ in darkness for 24 hrs. After this period the leaf injury index was evaluated $\left(\mathrm{LT}_{50}\right)$ in leaf disks by measuring changes in relative electrolyte conductivity caused by ion leakage (RC) according to Raymond et al. (1986). Thermal analyses were conducted with material from the same leaves in order to determine ice nucleation temperature (INT) and freezing temperature (FRT) (Larcher, 2003). With these values and $\mathrm{LT}_{50}$, it was possible to determine if a particular genotype was freezing sensitive (FS) or freezing toletant (FT). If ice nucleation temperature is higher than $\mathrm{LT}_{50}$, then the genotype is FT. Similarly, if ice nucletion temperature is lower than $\mathrm{LT}_{50}$, the genotype is FS. Essentially, this procedure was the same as used by Reyes-Díaz et al. (2005). Briefly, a piece of leaf was attached to a fine 


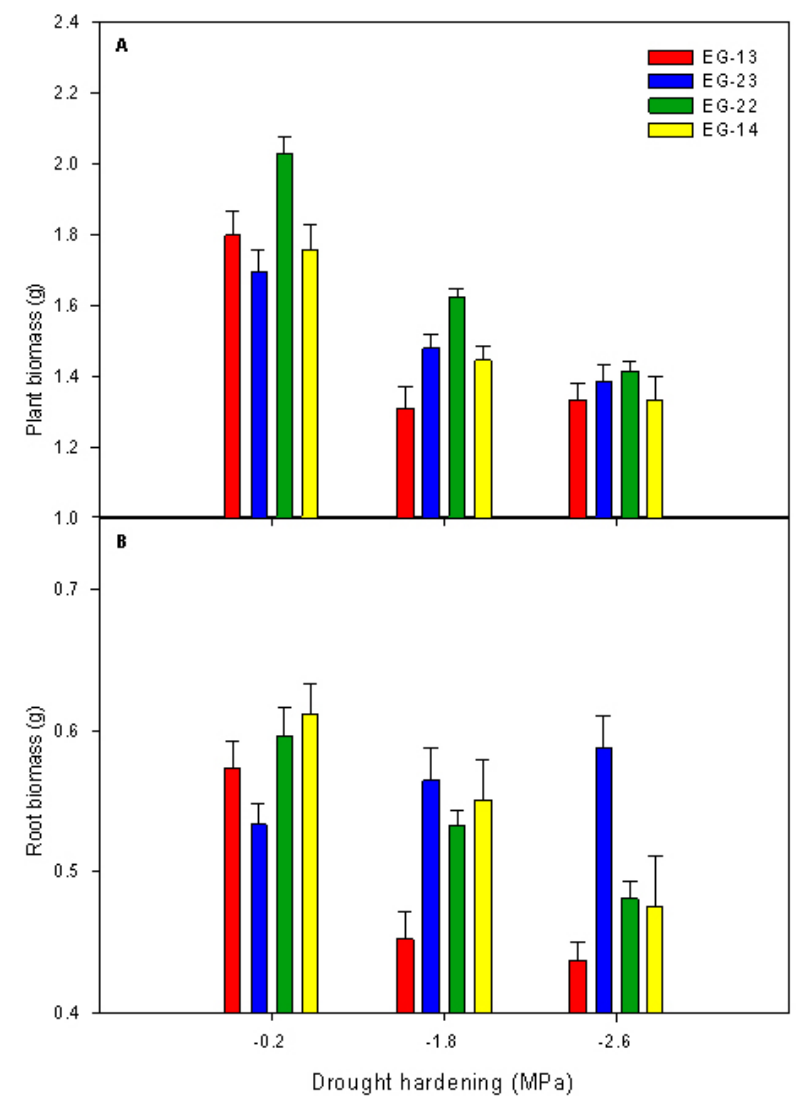

Figure 2. Intraspecific variations of plant and root biomasses of $E$. globulus genotypes in response to three drought hardening treatments. (a) Plant and (b) root biomass in four Eucalyptus globulus genotypes (EG-13, EG-23, EG-22 and EG-14) subjected to three different regimes of drought hardening $(-0.2,-1.8$ and $-2.6 \mathrm{MPa})$ evaluated at the end of the experiment (Day 54). Values are means $\pm 1 \mathrm{SE}, \mathrm{n}=40$.

copper-constantan type $\mathrm{T}$ thermocouple, gauge 30, junction diameter about $0.5 \mathrm{~mm}$ (Cole Palmer, Vernon Hills, IL USA). This sample was immediately enclosed in a cryotube to avoid tissue dehydration. Cryotubes were immersed in a cryostat (C25P, ThermoHaake, Karlsruhe, Germany) programmed to perform a linear descend from $0^{\circ}$ to $-15^{\circ} \mathrm{C}$ at a rate of $2^{\circ} \mathrm{C} \mathrm{h}^{-1}$. Temperature was continuously monitored and recorded every 1 sec with a USB data acquisition system (Personal Daq/56, IOtech. Inc, Cleveland, Ohio USA) connected to a personal computer.

\section{Data analyses}

There were no genotypic differences between $\Psi_{\text {pd }}$ during hardening. The variation in $\Psi_{\mathrm{pd}}$ of the average of genotypes ( $\mathrm{n}=80 ; 20$ by each genotype) was considered for the enforcement of drought hardening treatments. A factorial randomized block designs was use to examine the effect of drought hardening treatments(-0.2, -1.8 and -2.6 MPa) and genotypes (EG-13, EG-23, EG-22 and EG-14) on morphological characteristics $(\mathrm{n}=160$ for hardening regime and $n=120$ per genotype), and intraspecific variations of plant and root biomasses $(n=40)$, and cold injury, ice nucleation, and freezing temperatures $(n=5$ for thermal analysis and $n=8$ for the $L_{50}$ ). The factorial design was arranged in 4 spatial blocks (culture platforms) with 233 replicates (seedlings) of each combination of drought hardening treatmentsand genotypes. The experimental unit was the seedling. The sampling within each block was totally random. Data were analyzed by twoway ANOVA. All variables were subjected to normality and variance homogeneity tests prior to ANOVA. A posthoc Tukey test was applied when ANOVAS gave significant differences $(\mathrm{P} \leq 0.05)$. All these analyses were performed using the software STATISTICA (Version 6, 2001, StatSoft, Tulsa, OK).

\section{RESULTS}

\section{Growth and morphology}

Drought hardening treatments generated differential genotypes effects on seedlings allometry. At the end of the experiment, the interaction between genotypes and hardening treatment was significant only for plant $(\mathrm{P} \leq$ $0.05)$ and root biomass ( $\mathrm{P} \leq 0.01)$. Plant biomass decreased in the four genotypes as the stress treatment increased. However, there were no significant differences in plant biomass between genotypes hardened at -1.8 and -2.6 $\mathrm{MPa}$ (Figure 2a). The plant biomass of the EG-22 genotype only differed between the -0.2 and $-2.6 \mathrm{MPa}$ treatments. The plant biomass of EG-22 genotype hardened at $-0.2 \mathrm{MPa}$ was higher than the rest (Figure 2a). In the $-1.8 \mathrm{MPa}$ drought hardening treatment the EG-22 and EG-13 genotypes generated the highest and lowest plant biomass, respectively. The root biomass of EG-13 genotype showed the highest sensitivity to water stress, diminishing $22 \%$ in the -1.8 MPa treatment. The root biomass of EG-22 and EG-14 genotypes decreased only with the most severe hardening treatment $(-2.6 \mathrm{MPa})$. The genotypes root biomass did not differ within the control treatment $(-0.2$ $\mathrm{MPa})$. However, root biomasses of almost all genotypes differed with the hardening treatments at -1.8 and $-2.6 \mathrm{MPa}$. The EG-23 genotype showed a different trend: it's root biomass increased with the exposure to the most severe water stress treatment (Figure 2b). Mortality of plants by dehydration was low and did not differ among genotypes, but it was significantly different within treatments $(\mathrm{P} \leq$ 0.01). Plants exposed to -1.8 and $-2.6 \mathrm{MPa}$ only exhibited a mortality of $2.5 \%$ and $5.7 \%$, respectively.

The hardening treatments resulted in a significant decrease in plant height, leaf area, SLA, stem, and leaf biomasses, while collar diameter was not affected. The genotypes were not different in size at the beginning of the essay. However, they showed differential responses to drought hardening treatments in plant height, leaf area, SLA, and stem, and leaf biomasses (Table 1). 
Table 1. Morphological characteristics of four E. globulus genotypes subjected to three drought hardening regimes in nursery. Height, collar diameter, leaf area, specific leaf area, stem and leaf biomass in four Eucalyptus globulus genotypes (EG-13, EG-23, EG22 and EG-14) subjected to three different regimes of drought hardening $(-0.2,-1.8$ and $-2.6 \mathrm{MPa})$ evaluated at the end of the experiment (Day 54). Values are means \pm 1 SE $(n=160$ for hardening regime and $n=120$ per genotype). Means with different letters indicate significant differences $(\mathrm{P} \leq 0.05)$.

\begin{tabular}{|c|c|c|c|c|c|c|c|}
\hline Morphological & \multicolumn{3}{|c|}{ Hardening regime (MPa) } & \multicolumn{3}{c|}{ Genotype } \\
\hline characteristic & -0.2 & -1.8 & -2.6 & EG-13 & EG-23 & EG-22 & EG-14 \\
\hline Height $(\mathrm{cm})$ & $23.4 \pm 0.36 \mathrm{a}$ & $22.6 \pm 0.29 \mathrm{ab}$ & $21.8 \pm 0.28 \mathrm{~b}$ & $22.9 \pm 0.32 \mathrm{a}$ & $22.4 \pm 0.26 \mathrm{ab}$ & $23.6 \pm 0.41 \mathrm{a}$ & $21.5 \pm 0.38 \mathrm{~b}$ \\
\hline Collar diameter $(\mathrm{mm})$ & $2.34 \pm 0.04 \mathrm{a}$ & $2.34 \pm 0.04 \mathrm{a}$ & $2.25 \pm 0.04 \mathrm{a}$ & $2.26 \pm 0.04 \mathrm{a}$ & $2.27 \pm 0.06 \mathrm{a}$ & $2.34 \pm 0.03 \mathrm{a}$ & $2.36 \pm 0.04 \mathrm{a}$ \\
\hline Leaf area $\left(\mathrm{cm}^{2}\right)$ & $66.3 \pm 1.3 \mathrm{a}$ & $44.9 \pm 1.4 \mathrm{~b}$ & $37.3 \pm 1.2 \mathrm{c}$ & $51.3 \pm 3.2 \mathrm{a}$ & $41.3 \pm 2.7 \mathrm{~b}$ & $53.0 \pm 2.6 \mathrm{a}$ & $52.3 \pm 2.6 \mathrm{a}$ \\
\hline Specific leaf area $\left(\mathrm{cm}^{2} / \mathrm{g}\right)$ & $105 \pm 1.6 \mathrm{a}$ & $97 \pm 1.4 \mathrm{~b}$ & $90 \pm 1.5 \mathrm{c}$ & $98 \pm 2.0 \mathrm{ab}$ & $93 \pm 2.1 \mathrm{~b}$ & $99 \pm 1.9 \mathrm{ab}$ & $100 \pm 2.4 \mathrm{a}$ \\
\hline Stem biomass $(\mathrm{g})$ & $0.65 \pm 0.02 \mathrm{a}$ & $0.49 \pm 0.02 \mathrm{~b}$ & $0.43 \pm 0.01 \mathrm{c}$ & $0.51 \pm 0.03 \mathrm{bc}$ & $0.54 \pm 0.03 \mathrm{ab}$ & $0.57 \pm 0.02 \mathrm{a}$ & $0.47 \pm 0.02 \mathrm{c}$ \\
\hline Leaf biomass $(\mathrm{g})$ & $0.63 \pm 0.02 \mathrm{a}$ & $0.46 \pm 0.02 \mathrm{~b}$ & $0.42 \pm 0.02 \mathrm{~b}$ & $0.52 \pm 0.03 \mathrm{a}$ & $0.45 \pm 0.03 \mathrm{~b}$ & $0.53 \pm 0.02 \mathrm{a}$ & $0.53 \pm 0.03 \mathrm{a}$ \\
\hline
\end{tabular}

\section{Freezing resistance}

The interaction between drought hardening treatment and genotypes was significant for ice nucleation, freezing temperatures $(\mathrm{P} \leq 0.05)$ and $\mathrm{LT}_{50}(\mathrm{P} \leq 0.01)$. Hardening treatments at -0.2 and $-1.8 \mathrm{MPa}$ did not modify ice nucleation and freezing temperatures of EG-23 and EG-13 genotypes. However, both temperatures increased with the 2.6 MPa treatment in EG-13, EG-23 and EG-22 genotypes. These temperatures did not change with the hardening treatment in the EG-22 y EG-14 genotypes, with the exception of freezing temperature of EG-22 that was significantly reduced in the plants exposed to -1.8 MPa. Ice nucleation temperatures were significantly lower than freezing ones in all cases, except for the EG-22 clone after hardening at $-1.8 \mathrm{MPa}$ (Table 2). The $\mathrm{LT}_{50}$ of EG-13 and EG-23 genotypes at -0.2 and -2.6 MPa were similar and lower than at -1.8 MPa. The -1.8 and -2.6 MPa drought hardening treatments reduced the $\mathrm{LT}_{50}$ of EG-14 genotype, while the EG-22 genotype $\mathrm{LT}_{50}$ was not affected. When comparing genotypes in the $-0.2 \mathrm{MPa}$ drought hardening treatment, the genotypes decreased their freezing resistance in the following order EG-14, EG-22, EG-23 and EG-13. However, within genotypes hardened at -1.8 MPa, EG-14 showed the lowest $\mathrm{LT}_{50}$. The $\mathrm{LT}_{50}$ of all genotypes subjected to -2.6 MPa did not differ (Table 2).

\section{DISCUSSION}

\section{Water stress effects on growth and morphology}

Different intraspecific morphological responses to water stress have been reported in E. globulus seedlings (Osorio and Pereira, 1994; Costa e Silva et al. 2004). Drought hardening treatments, $-1.3 \mathrm{MPa}$ and $-2.4 \mathrm{MPa}$, applied under nursery conditions, significantly reduced plant height, leaf area, and specific leaf area, stem and leaf biomass in all evaluated E. globulus genotypes. Plant height, which is considered a predictor of growth potential in the field, was reduced $3 \%$ and $7 \%$ in treatments at -1.8 MPa and -2.6 MPa respectively. Nevertheless, excessive plant height is a disadvantage in water stressed sites (South and Zwolinski, 1997). A quality seedling planting stock is composed of the biggest possible seedlings which maintain acceptable levels of survival in a designated site (South et al. 2005). Collar diameter of nursery seedlings, which is considered the best predictor of survival and initial growth of plants in a plantation (South et al. 1995), did not differ within our drought hardening treatments neither among genotypes. The low responsiveness found in this morphological trait, could be beneficial because genotypes can be hardened without a trade off with morphological indicators of seedling quality. However, collar diameter can be effectively controlled by plant density (Mason, 2001). A particularly efficient mechanism to reduce the transpiratory surface is partial leaf abscission (Larcher, 2003). Drought hardened genotypes at -1.8 and -2.6 MPa reduced their leaf area in a $32 \%$ and $44 \%$, respectively. This variable is one of the most sensitive ones to water stress as reported by several studies in E. globulus (Osorio et al. 1998; Pita and Pardos, 2001; Costa e Silva et al. 2004). During our experiments, abscission of a significant foliage fraction (old and basal leaves) was observed, which is a known strategy to face drought in E. globulus (Coopman et al. 2008). The EG-23 genotype showed a lower leaf area than the other genotypes. According to Pita and Pardos (2001), the big leaf genotypes are of high risk for plants in drought prone areas. Drought hardening treatments of -1.8 MPa and -2.6 MPa significantly reduced SLA, $8 \%$ and $14 \%$, respectively. Similar results have been reported by Pita and Pardos, (2001); Costa e Silva et al. (2004). For E. globulus genotypes, the maintenance of the balance between 
transpiration and absorption areas when water availability is reduced seems to be a determinant key of seedlings performance under drought conditions (Hsiao and $\mathrm{Xu}$, 2000; Costa e Silva et al. 2004; McDowell et al. 2008). Finally, the biggest root biomass, smaller leaf area LA, and SLA of the EG-23 genotype are characteristics that would indicate a bigger capacity to tolerate drought relative to the other genotypes. In general, these changes are consistent with a higher water stress resistance after the acclimation period. Plants were re-watered after the acclimation period, but the morphological changes remained. For this reason, this material was considered fit to show that freezing resistance would be affected by morphological changes generated by water stress.

\section{Freezing resistance}

Thermal analyses combined with a freezing injury index $\left(\mathrm{LT}_{50}\right)$ allowed us to predict that the studied genotypes, at unstressed conditions, were not able to tolerate ice formation within their leaf tissues, showing incipient damage $\left(\mathrm{LT}_{10}\right)$ at higher temperatures that INT (data not shown). For this reason, we classified these 4 E. globulus genotypes as freezing sensitive. Nevertheless, the severe drought hardening treatment (-2.6 MPa) increased the ice nucleation temperature of EG-13, EG-23 and EG-22 genotypes, resulting in an $\mathrm{LT}_{50}$ lower than INT. This indicates that these genotypes became freezing tolerant with drought hardening. Commonly, the initial and main frost damage mechanism in cold exposed plants is cellular dehydration, induced by aploplastic water freezing and its consequences (Neuner and Bannister, 1995). Since ice crystals are formed outside the cell, freezing and drought are considered causal of cellular dehydration (Shinozaki and Yamaguchi-Shinozaki, 2000; Beck et al. 2007). Then, it is reasonable to suggest that similar modifications are required in the cell to tolerate both stresses (Beck et al. 2007). Consistently, we detected a change in the freezing resistance mechanism in EG-13, EG-23 and EG-22 genotypes. However, their $\mathrm{LT}_{50}$ were minimally modified by the water stress acclimation period. An exception was EG-14, which increased its $\mathrm{LT}_{50}$ at the medium stress level. Therefore, freezing resistance depends on genotype and water stress level, as in other tree species (Costa e Silva et al. 2007; Costa e Silva et al. 2009; Gimeno et al. 2009). This physiological variation of the stress-response of genotypes is important for the development of breeding

Table 2. Relationship between cold injury, ice nucleation and freezing temperature in four Eucalyptus globulus genotypes subjected to different drought hardening regimes. Values are means of 5 replicates for the thermal analysis and 8 replicates for the $\mathrm{LT}_{50} \pm 1 \mathrm{SE}$. Means with different letters are significantly different $(P \leq 0.05)$. Lower case letters compare nucleation and freezing temperatures (Columns and rows). Upper case letter compare only within the $L T_{50}$ column. $L T_{50}=$ lethal temperature for $50 \%$ of leaf cellular damage evaluated by relative conductivity; FS = freezing sensitive, FT = freezing tolerant.

\begin{tabular}{|c|c|c|c|c|c|}
\hline Genotype & $\begin{array}{l}\text { Hardening } \\
\text { regime } \\
(\mathrm{MPa})\end{array}$ & $\begin{array}{c}\text { Nucleation } \\
\text { temperature } \\
\left({ }^{\circ} \mathrm{C}\right)\end{array}$ & $\begin{array}{c}\text { Freezing } \\
\text { temperature } \\
\left({ }^{\circ} \mathrm{C}\right)\end{array}$ & $\begin{array}{l}\mathrm{LT}_{50} \\
\left({ }^{\circ} \mathrm{C}\right)\end{array}$ & $\begin{array}{c}\text { Freezing } \\
\text { resistance } \\
\text { category }\end{array}$ \\
\hline \multirow{3}{*}{ EG-13 } & -0.2 & $-7.3 \pm 0.2 \mathrm{~cd}$ & $-4.6 \pm 0.2$ efgh & $-7.7 \pm 0.2 \mathrm{E}$ & FS \\
\hline & -1.8 & $-7.6 \pm 0.3 d$ & $-4.9 \pm 0.1 \mathrm{fgh}$ & $-6.3 \pm 0.2 \mathrm{BC}$ & FS \\
\hline & -2.6 & $-5.8 \pm 0.2 \mathrm{abc}$ & $-3.0 \pm 0.2 \mathrm{e}$ & $-7.0 \pm 0.3 \mathrm{CDE}$ & $\mathrm{FT}$ \\
\hline \multirow{3}{*}{ EG-23 } & -0.2 & $-7.3 \pm 0.3 \mathrm{~cd}$ & $-5.3 \pm 0.4 \mathrm{gh}$ & $-7.6 \pm 0.2 \mathrm{E}$ & FS \\
\hline & -1.8 & $-7.0 \pm 0.3 \mathrm{bcd}$ & $-5.6 \pm 0.4 h$ & $-6.0 \pm 0.3 A B$ & FS \\
\hline & -2.6 & $-4.8 \pm 0.3 a$ & $-3.1 \pm 0.2 \mathrm{e}$ & $-7.0 \pm 0.2 \mathrm{CDE}$ & FT \\
\hline \multirow{3}{*}{ EG-22 } & -0.2 & $-6.5 \pm 0.3 \mathrm{abcd}$ & $-4.6 \pm 0.3$ efgh & $-6.8 \pm 0.0 \mathrm{BCD}$ & FS \\
\hline & -1.8 & $-6.8 \pm 0.7 \mathrm{bcd}$ & $-5.1 \pm 0.5$ bgh & $-6.7 \pm 0.1 \mathrm{BCD}$ & FS \\
\hline & -2.6 & $-5.4 \pm 0.3 a b$ & $-3.2 \pm 0.6$ ef & $-6.7 \pm 0.1 \mathrm{BCD}$ & FT \\
\hline \multirow{3}{*}{ EG-14 } & -0.2 & $-5.6 \pm 0.3 a b c$ & $-3.3 \pm 0.3$ ef & $-5.2 \pm 0.0 \mathrm{~A}$ & FS \\
\hline & -1.8 & $-5.8 \pm 0.3 a b c$ & $-3.9 \pm 0.2$ efgh & $-7.4 \pm 0.1 \mathrm{DE}$ & FT \\
\hline & -2.6 & $-5.9 \pm 0.5 \mathrm{abcd}$ & $-3.6 \pm 0.4$ efg & $-6.6 \pm 0.1 \mathrm{BCD}$ & FS \\
\hline
\end{tabular}


programmes and is essential to support decisions to allocate genotypes to different climatic planting sites (Shvaleva et al. 2008). In reforestation, seedlings are usually planted in autumn to avoid drought, but this may render the seedlings susceptible to autumn and winter frosts. Measuring freezing resistance 3 weeks after water stress was relieved appears to be an appropriate way to find semi-permanent changes induced by water stress. Water stress metabolites decrease during the deacclimation period (Dichio et al. 2006; Shvaleva et al. 2006; Dichio et al. 2009), but the more permanent seedlings morphological changes remain. Increasing drought resistance before plants are transferred from nurseries to the field seems a useful nursery silvicultural practice to improve plantation success.

\section{REFERENCES}

BECK, Erwin H.; HEIM, Richard and HANSEN, Jen. Plant resistance to cold stress: Mechanisms and environmental signals triggering frost hardening and dehardening. Journal of Bioscience, December 2004, vol. 29, no. 4, p. 449-459.

BECK, Erwin H.; FETTIG, Sebastian; KNAKE, Claudia; HARTIG, Katja and BHATTARAI, Tribikram. Specific and unspecific responses of plants to cold and drought stress. Journal of Bioscience, April 2007, vol. 32, no. 3, p. 501-510.

CLOSE, D.C.; BEADLE, C.L. and BATTAGLIA, M. Foliar anthocyanin accumulation may be a useful indicator of hardiness in eucalypt seedlings. Forest Ecology and Management, August 2004, vol. 198, no. 1-3, p. 169-181.

COOPMAN, Rafael E.; JARA, Jorge C.; BRAVO, Leon A.; SAÉZ, Katia L.; MELLA, Gloria R. and ESCOBAR, Rene. Changes in morpho-physiological attributes of Eucalyptus globulus plants in response to different drought hardening treatments. Electronic Journal of Biotechnology, April 2008, vol. 11, no. 2, p. 1-10.

COSTA E SILVA, F.; SHVALEVA, A.; MAROCO, J.P.; ALMEIDA, M.H.; CHAVES, M.M. and PEREIRA, J.S. Responses to water stress in two Eucalyptus globulus clones differing in drought tolerance. Tree Physiology, August 2004, vol. 24, no. 10, p. 1165-1172.

COSTA E SILVA, Felipe; SHVALEVA, Alla; ALMEIDA, M. Helena; CHAVES, M. Manuela and PEREIRA, João S. Responses to chilling of two Eucalyptus globulus clones with contrasting drought resistance. Functional Plant Biology, November 2007, vol. 34, no. 9, p. 793-802.

COSTA E SILVA, F.; SHVALEVA, A.; BROETTO, F.; ORTUÑO, M.F.; RODRIGUES, M.L.; ALMEIDA, M.H.; CHAVES, M.M. and PEREIRA, J.S. Acclimation to shortterm low temperatures in two Eucalyptus globulus clones with contrasting drought resistance. Tree Physiology, January 2009, vol. 29, no. 1, p. 77-86.

DICHIO, Bartolomeo; XILOYANNIS, Cristos; SOFO, Adriano and MONTANARO, Giuseppe. Osmotic regulation in leaves and roots of olive trees during a water deficit and rewatering. Tree Physiology, February 2006, vol. 26, no. 2, p. 179-185.

DICHIO, Bartolomeo; MARGIOTTA, Giovanna; XILOYANNIS, Cristos; BUFO, Sabino A.; SOFO, Adriano and CATALDI, Tommaso R.I. Changes in water status and osmolyte contents in leaves and roots of olive plants (Olea europaea L.) subjected to water deficit. Trees, April 2009, vol. 23, no. 2, p. 247-256.

EWERS, B.E.; OREN, R. and SPERRY, J.S. Influence of nutrient versus water supply on hydraulic architecture and water balance in Pinus taeda. Plant Cell \& Environment, October 2000, vol. 23, no. 10, p. 1055-1066.

GIMENO, Teresa E.; PIAS, Beatriz; LEMOS-FILHO, Jose P. and VALLADARES, Fernando. Plasticity and stress tolerance override local adaptation in the responses of Mediterranean holm oak seedlings to drought and cold. Tree Physiology, January 2009, vol. 29, no. 1, p. 87-98.

HAASE, Diane L.; ROSE, Robin and TROBAUGH, John. Field performance of three stock sizes of Douglas-fir container seedlings grown with slow-release fertilizer in the nursery growing medium. New Forests, January 2006, vol. 31, no. 1, p. 1-24.

HSIAO, Theodore C. and XU, Liu-Kang. Sensitivity of growth of roots versus leaves to water stress: biophysical analysis and relation to water transport. Journal of Experimental Botany, September 2000, vol. 51, no. 350, p. 1595-1616.

LANDIS, Thomas D. Irrigation and water management. In: LANDIS, T.D.; TINUS, R.W.; MCDONALD, S.E. and BARNET, J.P. eds. The container tree nursery manual. Washington, D.C., U.S. Department of Agriculture, Forest Service, 1989, vol. 4, p. 69-118.

LARCHER, Walter. Physiological plant ecology: ecophysiology and stress physiology of functional groups. $4^{\text {th }}$ ed. New York; Springer Press, 2003. 513 p. ISBN 9783540435167.

LINDER, S.; BENSON, M.L.; MYERS, B.J. and RAISON, R.J. Canopy dynamics and growth of Pinus radiata. I. Effects of irrigation and fertilization during a drought. Canadian Journal of Forest Research, October 1987, vol. 17, no. 10, p. 1157-1165.

MASON, E.G. A model of the juvenile growth and survival of Pinus radiata D. Don; Adding the effects of initial 
seedling diameter and plant handling. New Forests, September 2001, vol. 22, no. 1-2, p. 133-158.

MCDOWELL, Nate; POCKMAN, William T.; ALLEN, Craig D.; BRESHEARS, David D.; COBB, Neil; KOLB, Thomas; PLAUT, Jennifer; SPERRY, John; WEST, Adam; WILLIAMS, David G. and YEPEZ, Enrico A. Mechanisms of plant survival and mortality during drought: why do some plants survive while others succumb to drought? New Phytologist, June 2008, vol. 178, no. 4, p. 719-739.

NEUNER, G. and BANNISTER, P. Frost resistance and susceptibility to ice formation during natural hardening in relation to leaf anatomy in three evergreen tree species from New Zealand. Tree Physiology, June 1995, vol. 15, no, 6, p. 371-377.

OSORIO, J. and PEREIRA, J.S. Genotypic differences in water use efficiency and ${ }^{13} \mathrm{C}$ discrimination in Eucalyptus globulus. Tree Physiology, July-September 1994, vol. 14, no. 7-8-9, p. 871-882.

OSORIO, J.; OSORIO, M.L.; CHAVES, M.M. and PEREIRA, J.S. Water deficits are more important in delaying growth than in changing patterns of carbon allocation in Eucalyptus globulus. Tree Physiology, June 1998, vol. 18, no. 6, p. 363-373.

PEARCE, Roger S. Plant freezing and damage. Annals of Botany, April 2001, vol. 87, no. 4, p. 417-424.

PITA, Pilar and PARDOS, José A. Growth, leaf morphology, water use and tissue water relations of Eucalyptus globulus clones in response to water deficit. Tree Physiology, June 2001, vol. 21, no. 9, p. 599-607.

RAYMOND, C.A.; HARWOOD, C.E. and OWEN, J.V. A conductivity method for screening populations of Eucalypts for frost damage and frost tolerance. Australian Journal of Botany, January 1986, vol. 34, no. 4, p. 377-393.

REYES-DÍAZ, Marjorie; ALBERDI, Miren; PIPER, Fidra; BRAVO, León Aloys and CORCUERA, Luis Julián. Low temperature responses of Nothofagus dombeyi and Nothofagus nitida, two evergreen species from South Central Chile. Tree Physiology, November 2005, vol. 25, no. 11, p. 1389-1398.

ROYO, Antonio; GIL, Luis and PARDOS, José A. Effect of water stress conditioning on morphology, physiology and field performance of Pinus halepensis Mill. seedlings. New Forests, March 2001, vol. 21, no. 2, p. 127-140.

SHINOZAKI, Kazuo and YAMAGUCHI-SHINOZAKI, Kazuko. Molecular responses to dehydration and low temperature: differences and cross-talk between two stress signaling pathways. Current Opinion in Plant Biology, August 2000,vol. 3, no. 3, p. 217-223.
SHVALEVA, A.L.; COSTA E SILVA, F.; BREIA, E.; JOUVE, J.; HAUSMAN, J.F.; ALMEIDA, M.H.; MAROCO, J.P.; RODRIGUES, M.L.; PEREIRA, J.S. and CHAVES, M.M. Metabolic responses to water deficit in two Eucalyptus globulus clones with contrasting drought sensitivity. Tree Physiology, February 2006, vol. 26, no. 2, p. 239-248.

SHVALEVA, Alla; COSTA E SILVA, Felipe; SCOTTI, Paula; OUFIR, Mouhssin; HAUSMAN, Jean-François; CEDRIC, Guignard; RAMOS, Paula; ALMEIDA, M. Helena; RODRIGUES, M. Lucília; PEREIRA, João S. and CHAVEZ, M. Manuela. Physiological and biochemical responses to low non-freezing temperature of two Eucalyptus globulus clones differing in drought resistance. Annals of Forest Science, March-April 2008, vol. 65, no. 2, p. 204.

SOUTH, David B.; ZWOLINSKI, Janusz B. and ALLEN, H. Lee. Economic returns from enhancing loblolly pine establishment on two upland sites: Effects of seedling grade, fertilization, hexazinone, and intensive soil cultivation. New Forests, November 1995, vol. 10, no. 3, p. 239-256.

SOUTH, David B. and ZWOLINSKI, Janusz B. Transplant stress index: A proposed method of quantifying planting check. New Forests, May 1997, vol. 13, no. 1-3, p. 315328.

SOUTH, David B.; ROSE, Robin W. and MCNABB, Ken L. Nursery and site preparation interaction research in the United States. New Forests, January 2001, vol. 22, no. 1-2, p. 43-58.

SOUTH, David B.; MENZIES, Mike I. and HOLDEN, D. Grant. Stock size affects outplanting survival and early growth of fascicle cuttings of Pinus radiata. New Forests, March 2005, vol. 29, no. 3, p. 273-288.

SUNDHEIM FLØISTAD, Inger and KOHMANN, Ketil. Influence of nutrient supply on spring frost hardiness and time of bud break in Norway spruce (Picea abies (L.) Karst.) seedlings. New forests, January 2004, vol. 27, no. 1, p. 1-11.

TIBBITS, Wayne N.; WHITE, Timothy L.; HODGE, Gary R. and BORRALHO, Nuno M.G. Genetic variation in frost resistance of Eucalyptus globulus ssp. globulus assessed by artificial freezing in winter. Australian Journal of Botany, September 2006, vol. 54, no. 6, p. 521-529.

THOMAS, F.M. and AHLERS, U. Effects of excess nitrogen on frost hardiness and freezing injury of aboveground tissue in young oaks (Quercus petraea and $Q$. robur). New Phytologist, October 1999, vol. 144, no. 1, p. 73-83.

VAN DEN DRIESSCHE, R. Changes in drought resistance and root growth capacity of container seedlings in response 
to nursery drought, nitrogen, and potassium treatments. Canadian Journal of Forest Research, May 1992, vol. 22, no. 5, p. 740-749.

VILLAR-SALVADOR, P.; PLANELLES, R.; ENRIQUEZ, E. and PEÑUELAS-RUBIRA, J. Nursery cultivation regimes, plant functional attributes, and field performance relationships in the Mediterranean oak Quercus ilex L. Forest Ecology and Management, July 2004a, vol. 196, no. 2-3, p. 257-266.

VILLAR-SALVADOR, Pedro; PLANELLES, Rosa; OLIET, Juan; PEÑUELAS-RUBIRA, Juan L.; JACOBS, Douglas F. and GONZÁLES, Magdalena. Drought tolerance and transplanting performance of holm oak (Quercus ilex) seedlings after drought hardening in the nursery. Tree Physiology, October 2004b, vol. 24, no. 10, p. 1147-1155.

WIKBERG, Jenny and ÖGREN, Erling. Variation in drought resistance, drought acclimation and water conservation in four willow cultivars used for biomass production. Tree Physiology, September 2007, vol. 27, no. 9, p. 1339-1346. 